\title{
Low density of prickly acacia under sheep grazing in Queensland
}

\author{
FLEUR TIVER, MIKE NICHOLAS, DARREN KRITICOS, AND JOEL R. BROWN
}

The first author is senior lecturer in ecology, School of Environmental Management, University of South Australia, Mawson Lakes, South Australia 5095. At the time of the research, she was a research scientist, CSIRO Division of Tropical Crops \& Pastures, Davies Laboratory, Aitkenvale, Townsville, Queensland 4814. The $2^{\text {nd }}$ author is a research officer, CSIRO Division of Tropical Agriculture, Davies Laboratory, Aitkenvale, Townsville. At the time of writing the $3^{\text {rd }}$ author was a doctoral student at the Cooperative Research Centre for Tropical Pest Management, Gehrmann Laboratories, University of Queensland, Brisbane, and is now a post-doctoral research fellow, Cooperative Research Centre for Weed Management Systems, CSIRO Entomology, GPO Box 1700, Canberra ACT 2601, Australia. The $4^{\text {th }}$ author is a senior research scientist with the USDA/NCRS, Jornada Experimental Range, PO Box 32003, MSC 3JER, New Mexico State University, Las Cruces, N.M 88003-8003, USA. At the time of the research he was a project officer, CSIRO Division of Tropical Crops \& Pastures, Davies Laboratory, Aitkenvale, Townsville, Queensland.

\section{Abstract}

Populations of an introduced woody weed, prickly acacia (Acacia nilotica (L.) Delile ssp. indica (Benth.) Brenan syn. Acacia arabica (Lam.) Willd. ssp. indica Benth.), were surveyed at 4 sites in central Queensland. There is a significantly lower frequency of plants of $<3 \mathrm{~m}$ in height within populations which have been grazed by sheep, indicating that browsing by sheep reduces regeneration. There were higher losses of seedlings at a sheep-grazed site than at cattle-grazed sites. These results support previous assertions that prickly acacia is regenerating more successfully on cattle properties, because cattle both disperse seeds and are less effective herbivores. In regions of low annual rainfall, prickly acacia is capable of forming dense stands (up to 2,700 shrubs $\mathrm{ha}^{-1}$ ) in lowland landscape types. Stands are less dense in upland landscapes (maximum of $718 \mathrm{shrubs} \mathrm{ha}^{-1}$ ). Of most concern is that in regions of high annual rainfall prickly acacia can form extremely dense thickets across most landscape types (up to 3,400 shrubs ha ${ }^{-1}$ ). We suggest that prickly acacia is most likely to become a management problem on cattle properties, and an extreme problem in high annual rainfall areas. The inclusion of sheep in livestock rotations may be an effective control measure in the Mitchell Grasslands, but this may not always be possible. A high priority is to prevent prickly acacia from expanding its range into equivalent high rainfall areas within Queensland, and also in the Northern Territory, northern New South Wales, and Western Australia. This could be achieved by quarantining livestock which have come from infested properties until seeds have passed through the digestive tract, after about 6 days. Management strategies at the property level should aim to prevent further spread of prickly acacia by controlling cattle movements between paddocks during periods when cattle are ingesting pods and seeds.

The authors wish to thank the following landholders for access to land and assistance with historical grazing information: Mr Gordon Smith of Bowen; Messrs Mic and Cec Burry of Giru; Alan Davidson of Nocoleche Station, Hughenden; Management and staff of Marathon Station, Richmond; Mr and Mrs K.J. Cameron of Allaru Station, Richmond; Mr and Mrs B. Fells of Garomna Station, Julia Creek, and Trevor Mitchell of the Queensland Department of Lands, Hughenden. Marnie McCulloch and Debbie Atkins of the Queensland Department of Primary Industries in Bowen provided assistance in locating sites. Funding for this project was provided by a CSIRO Multi-Divisional Project as part of the Tropical Agri-Export Program. Tony Grice and Jim Noble critically reviewed the manuscript.

Manuscript accepted 16 Sept. 2000.

\section{Resumen}

En 4 sitios de la región central de Queensland se muestrearon poblaciones de una maleza leñosa introducida, "Prickly acacia" (Acacia nilotica (L.) Delile ssp indica (Benth.) brenan syn Acacia arabica (Lam) Willd. ssp indica Benth.). Dentro de poblaciones que han sido apacentadas por ovinos hay una frecuencia significativamente menor de plantas de $<3 \mathrm{~m}$ de altura, indicando que el ramoneo por ovinos reduce la regeneración. Hubo mayores perdidas de plántulas en los sitios apacentados por ovinos que en los sitios apacentados por bovinos. Estos resultados avalan afirmaciones previas respecto a que el "Prickly acacia" se esta regenerando mas exitosamente en los ranchos que son explotados con bovinos porque dispersan las semillas y son herbívoros menos efectivos. En regiones de baja precipitación anual el "Prickly acacia"es capaz de formar poblaciones densas (hasta 2,700 arbustos ha $^{-1}$ ) en tipos de paisaje de tierras bajas. Las poblaciones son menos densas en terrenos altos (máximo 718 arbustos ha-1). La preocupación mas frecuente es que en regiones de alta precipitación anual el "Prickly acacia" forme poblaciones extremadamente densas en la mayoría de los tipos de paisaje (hasta 3,400 arbustos ha-1). Sugerimos que el "Prickly acacia" es mas probable que llegue a ser un problema de manejo en las propiedades de bovinos y un problema extremo en áreas con alta precipitación anual. La inclusión de ovinos en las rotaciones de ganado puede ser una medida de control efectiva en los pastizales Mitchell, pero esto no siempre es posible. Una alta prioridad es el evitar la expansión del rango del "Prickly acacia" a áreas equivalentes de alta precipitación dentro de Queensland, del Territorio del Norte, del norte del Nuevo Sur de Galeso y el oeste de Australia. Esto se puede lograr cuarentenando el ganado que viene de propiedades infestadas hasta que las semillas hayan pasado a través de tracto digestivo, aproximadamente después de 6 días. Se deben promover estrategias de manejo a nivel de propiedad para prevenir la dispersión del "Prickly acacia" mediante el control de los movimientos de ganado entre potreros con bovinos que están consumiendo vainas y semillas.

Key Words: Life-stage profiles, rainfall, population dynamics, regeneration, cattle, woody weeds

Prickly acacia (Acacia nilotica (L.) Delile ssp. indica (Benth.) Brenan syn. Acacia arabica (Lam.) Willd. ssp. indica Benth.) was introduced into the Mitchell Grass Plains of western Queensland in the 1890s as a source of shade and fodder (Barker 
1996). From western Queensland, prickly acacia has spread as far as Cooktown in far north Queensland, south to Coonamble in New South Wales, west to the Barkly Tablelands and Arnhem Land in Northern Territory and east to the coast of Queensland, an area approaching 4 million $\mathrm{km}^{2}$. It is now listed as a category 1 weed for northern Australia, that is: a terrestrial species which has extensive continental distribution and is capable of destroying an ecosystem (Humphries et al. 1991).

Rapidly increasing populations of both native and exotic shrubs, often called "woody weeds", which cause disruption of ecosystems and reduction of rangeland productivity have been well documented in the USA (Hennessy et al. 1983, Archer 1989, 1984, Brown and Archer 1989), southern Africa (Skarpe 1990, Holmes and Cowling 1997) as well as in Australia (PNSW 1901, Moore 1969, Harrington et al. 1984, Humphries et al. 1991). Efforts to control shrubs by clearing and poisoning have generally proved unsuccessful and uneconomic. Such methods are expensive for the degree of control achieved, and there is only a short to medium term benefit in increased livestock returns per hectare, particularly on properties where stocking rates are low regardless of shrub densities. Control strategies are more likely to be implemented if they are economical and aligned with existing management practices, and more likely to be successful if based on ecological principles (Harrington 1979, Adamson and Fox 1982, Jacoby 1985). Any alteration in the establishment of new individuals into the population can have dramatic effects on the long-term survival of plant populations (Harper 1977). The survivorship of seedlings is crucial to shrub regeneration so it is logical to examine this portion of the life cycle of a plant when developing a management strategy.

A widespread change from sheep to cattle-based enterprises in the Richmond Shire may have contributed to the increase of prickly acacia since 1973/74 (Carter 1994). Originally, leases in the western districts were only legally permitted to carry sheep. This requirement was relaxed during the 1960s and 70s and increased cattle prices encouraged many landholders to switch from sheep to cattle-based enterprises. Both sheep and cattle are known to eat the pods of prickly acacia but cattle chew seeds very ineffectively compared to sheep, pass a larger proportion of viable seeds in their dung and hence are more effective dispersal agents than sheep.
Cattle pass about $81 \%$ of ingested seed intact of which $15 \%$ are germinable (Harvey 1981), giving $41 \%$ germinability from those ingested (Barker 1996). Sheep pass $<1 \%$ of prickly acacia seeds intact of which 33\% are germinable (Harvey 1981, Carter et al. 1991, Barker 1996). Sheep tend to regurgitate large numbers of seeds during ingestion of the pods $(35 \%)$ and rumination (14\%) (Carter and Cowan 1993) hence depositing the seeds close to source and contributing little to increased range of prickly acacia. Cattle have been shown to disperse the seeds of mesquite (Prosopis) in North America (Brown and Archer 1987). The gut bacterial flora of large herbivores has been shown to destroy larvae of beetles from the family Bruchidae which would otherwise consume the seeds in which they are present (Miller 1994). This means that large herbivores not only act as dispersal agents, they also protect the seed from one of the potentially most important predators. The process of digestion also scarifies the seeds, thus increasing germinability of deposited seeds and further increasing the potential of large herbivores to spread prickly acacia.

The objective of this study was to survey existing populations of prickly acacia and to determine if the species of livestock used for rangeland enterprises (sheep and cattle) are each associated with differences in seedling survival and population densities of prickly acacia.

\section{Materials and Methods}

\section{Background}

Prickly acacia was deliberately introduced to western Queensland at least by 1926, when it was recommended as a shade and fodder species by the Queensland Department of Agriculture and Stock (Barker 1996). It was not listed as a significant exotic in western Queensland in 1938 (Blake 1938). Although prickly acacia became naturalized along creeks and boredrains (artificial drains where artesian water from the Great Artesian Basin is channelled for livestock), it did not appear to cause widespread concern until the 1970 s. There were several above-average rainfall years in the early 1970s, including 1973 and 1974 when the annual rainfall was around twice the average (ABM 1996). These periods of high rainfall are associated with La Niña phases of the El Niño-Southern Oscillation (ENSO) patterns which control the climate of the Pacific Ocean and eastern Australia (Nicholls 1991). During 1974 much of the low-lying country in western Queensland was flooded for weeks and local pastoralists report that there was a mass germination of prickly acacia following these floods. Pods are indehiscent, so the seeds remain in the pods unless consumed by herbivores. We have observed that pods are capable of floating for up to 30 hours in water with $67 \%$ subsequent germination so the floods may have served a dual purpose of dispersing seeds and also scarifying them by softening the seed-coat and leaching growth inhibitors.

\section{The Study Area}

Eight sites in prickly acacia stands were chosen in central Queensland; locations and rainfall are shown in Fig. 1 and Table 1. Average annual rainfall data from the nearest recording centres to each site (Giru, Bowen, Hughenden, Richmond and Julia Creek) were obtained from the Australian Bureau of Meteorology, and had been collected for 60-100 years, depending on the time of establishment of the recording stations at these centres (ABM 1996). Two high rainfall (989 and $1,164 \mathrm{~mm}$ ) sites were near the coast south of Townsville (Giru and Bowen). It is very difficult to determine the original vegetation at these sites because of the large degree of alteration to the vegetation cover through cultivation for sugar cane, introduction of pasture species for cattle-grazing, and invasion by woody weeds including prickly acacia and others such as paloverde (Parkinsonia aculeata L.). The sites appear to have originally been teatree (Melaleuca spp.) swampy woodlands. The remaining 6 sites were at inland, low annual rainfall $(420-487 \mathrm{~mm})$ areas in central western Queensland between Hughenden and Julia Creek. These sites were originally open plains dominated by Mitchell grass (Astrebla spp.). The landholders supplied information on grazing histories for the previous 20 years or more. The 2 coastal sites (Giru and Bowen) and one of the Hughenden sites (Marathon Station) have been exclusively grazed by cattle for $\geq 25$ years. The remaining Hughenden site (Nocoleche Station) is grazed by cattle. The 2 sites at Richmond (Allaru Station) are grazed predominantly by sheep, with very occasional access by cattle to the site. The 2 sites at Julia Creek (Garomna Station) have been grazed by sheep only, and one was unstocked during the seedling study. 


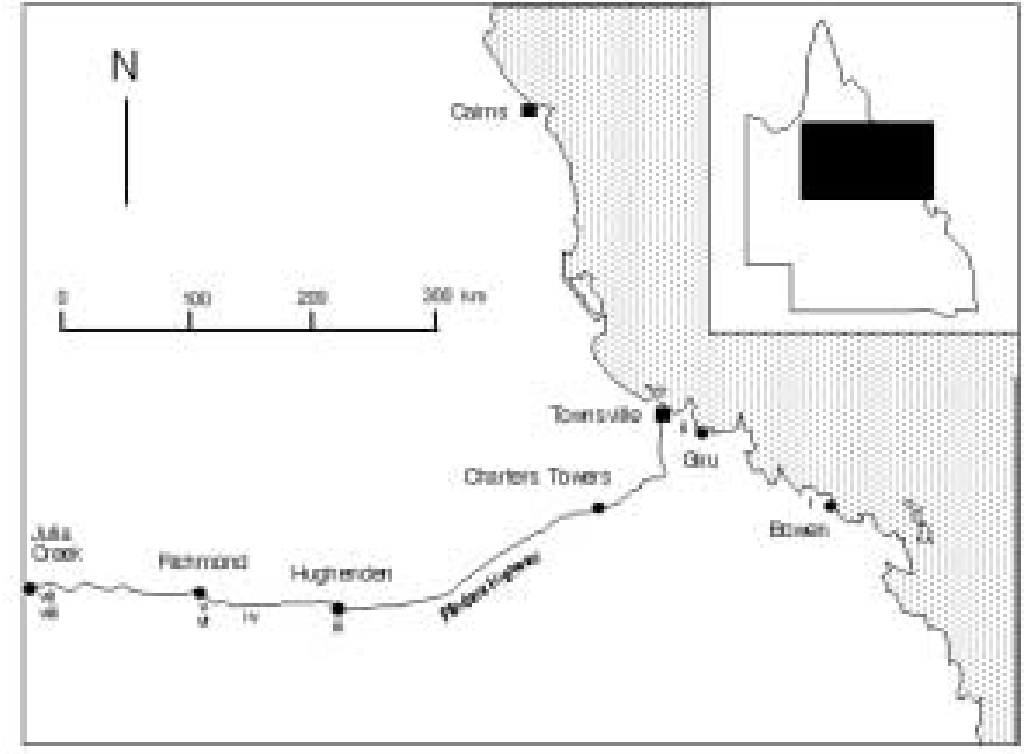

Fig. 1. The study area in central Queensland (inset) showing the location of 8 sites in prickly acacia (Acacia nilotica) populations. The sites at Giru, Bowen, and Hughenden are grazed by cattle, and the sites at Richmond and Julia Creek are grazed by sheep. The coastal sites, Giru and Bowen have about double the annual rainfall (around $1000 \mathrm{~mm}$ ) of the inland sites (around $450 \mathrm{~mm}$ ) (see Table 1).

\section{Population Structures \& Population Densities}

Size structure profiles of each population were developed from 20 individuals located by a "random walk" transect method (Kent and Coker 1992, Silvertown and Lovett-Doust 1993) and the results plotted as frequency distributions. Differences between sheep and cattle grazed sites were analysed by t-test. At 6 of the sites, the height of the nearest tree within each of the 4 compass quadrants was measured each $20 \mathrm{~m}$ along a $400 \mathrm{~m}$ transect, giving a size profile for each population based on 80 individuals per site. Density of prickly acacia at each landscape type within each site was calculated as follows. The distance to each of the trees in each quadrant was measured using a point-centred quarter plotless sampling technique. These were later used to calculate plant densities (D) using the formula:

$$
\mathrm{D}=20 / \sum_{\mathrm{m}=1}^{20}\left(\sum_{\mathrm{n}=1}^{4} \mathrm{~d}, \mathrm{n} / 4\right)^{2}
$$

where $\mathrm{d}$ is the distance to the trunk of the nearest tree in each quadrant $n$, and $m$ is the tree number (Cottam and Curtis 1956, Greig-Smith 1983). Differences in population densities between sites and landscape types within sites were analysed by ANOVA. Meteorology (ABR 1996).

\section{Seedling Survival}

Following rain in January 1995, cohorts of acacia seedlings were observed at Giru, Bowen, Nocoleche, Allaru, and Garomna North. At each site over 60 seedlings were located and their positions recorded using a measuring tape placed between 2 permanent marking stakes.

Seedling location was recorded as a pair of coordinates, distance along the tape in $\mathrm{m}$ and distance and direction at right angles from the tape in $\mathrm{cm}$. Seedlings were tagged with plastic poultry leg-rings. Two rings were placed on each plant, in different combinations of 6 colours so that individuals could be found and identified easily. The cohorts were visited every 3 weeks and individuals which had died due to desiccation recorded. In this case, the plant was still present with the rings intact. Where rings were scattered and the seedling missing from its recorded position, it was assumed that the seedling had been either trampled or grazed, thus allowing the rings to come off. These seedlings were recorded as missing since it was usually not possible to determine with certainty whether they had been trampled or grazed. Cohorts were followed until July 1995. The experiment was located opportunistically rather than by design. It is therefore not replicated and the results were not statistically analysed, but presented in summarized format only.

\section{Results}

\section{Population Densities}

Densities of prickly acacia at 6 sites are given in Table 2. Prickly acacia can form very dense stands, especially in high annual rainfall regions of coastal Queensland such as Bowen $\left(3,381\right.$ shrubs $\left.\mathrm{ha}^{-1}\right)$. Extremely dense stands were also recorded at Giru $\left(5,059\right.$ shrubs ha $\left.^{-1}\right)$, a high rainfall site which had been chained approximately 15 years previously (C. Burry pers. comm.). At the high annual rainfall sites, shrub densities were highest on welldrained sites (uplands and plains) whereas a poorly drained floodzone supported lower density shrubs $\mathrm{ha}^{-1}$. Prickly acacia has also formed dense stands at low annual rainfall in the Mitchell grasslands of inland Queensland, but only in and adjacent to boredrains (shallow earth channels built to carry water flowing from uncapped artesian bores for livestock) and in creeklines which receive extra water from surface flow. Densities were as high as 1,150 shrubs ha ${ }^{-1}$ on the bank of a boredrain at Allaru North but on upland landscapes the maximum was 354 shrubs ha $^{-1}$ at Marathon.

Table 1. Locations (recorded by GPS) and precipitation data of 8 prickly acacia (Acacia nilotica) sites in central Queensland.Rainfall data were obtained from the Australian Bureau of

\begin{tabular}{|c|c|c|c|c|}
\hline Site & Coordinates & $\begin{array}{l}\text { Nearest Rainfall } \\
\text { Recording Station }\end{array}$ & $\begin{array}{l}\text { Median } \\
\text { Rainfall }\end{array}$ & $\begin{array}{l}\text { Years of } \\
\text { Rainfall Records }\end{array}$ \\
\hline & & & $(\mathrm{mm})$ & (years) \\
\hline Giru & $20^{\circ} 28^{\prime} 14^{\prime \prime} \mathrm{S} 147^{\circ} 7^{\prime} 5^{\prime \prime} \mathrm{E}$ & Giru PO & 1164 & 1929-1993 \\
\hline Bowen & $20^{\circ} 3^{\prime} 45^{\prime \prime} \mathrm{S} \quad 148^{\circ} 12^{\prime} 23^{\prime \prime} \mathrm{E}$ & Bowen PO & 988 & 1871-994 \\
\hline Nocoleche & $20^{\circ} 54^{\prime} 39^{\prime \prime} \mathrm{S} 144^{\circ} 10^{\prime} 33^{\prime \prime} \mathrm{E}$ & Hughenden PO & 483 & 1884-1994 \\
\hline Marathon & $20^{\circ} 54^{\prime} 44^{\prime \prime} \mathrm{S} 143^{\circ} 34^{\prime} 00^{\prime \prime} \mathrm{E}$ & Richmond PO & 425 & 1890-1994 \\
\hline Allaru North & $20^{\circ} 45^{\prime} 16^{\prime \prime} \mathrm{S} 143^{\circ} 09^{\prime} 10^{\prime \prime} \mathrm{E}$ & Richmond PO & $"$ & $"$ \\
\hline Allaru South & $20^{\circ} 46^{\prime} 8^{\prime \prime} \mathrm{S} 143^{\circ} 9^{\prime} 10^{\prime \prime} \mathrm{E}$ & Richmond PO & " & $"$ \\
\hline Garomna North & $20^{\circ} 40^{\prime} 7^{\prime \prime} \mathrm{S} 141^{\circ} 47^{\prime} 28^{\prime \prime} \mathrm{E}$ & Julia Creek PO & 422 & 1913-994 \\
\hline Garomna South & $20^{\circ} 42^{\prime} 8^{\prime \prime} \mathrm{S} 141^{\circ} 50^{\prime} 51^{\prime \prime} \mathrm{E}$ & Julia Creek PO & $"$ & " \\
\hline
\end{tabular}


Table 2. Mean densities (shrubs ha ${ }^{-1}$ ) of prickly acacia (Acacia nilotica) at 6 sites in northern Queensland. Densities differ significantly $(F=6.84, \mathrm{df}=5,113, \mathrm{p}=\mathbf{0 . 0 0 0 1})$ by anova. Numbers of trees within each landscape type are shown in brackets. Densities between coastal sites (Giru and Bowen are significantly different from those at the inland sites (Nocoleche, Marathon, Allaru North and Garomna North $)(t=4.182, d f=117, p=0.0001)$.

\begin{tabular}{|c|c|c|c|}
\hline Site & $\begin{array}{l}\text { Landscape type } \\
(\mathrm{n}=\text { no. of trees) }\end{array}$ & Density & Site Mean \\
\hline Giru & $\begin{array}{l}\text { upland/plain }(\mathrm{n}=10) \\
\text { floodzone }(\mathrm{n}=7) \\
\text { swamp }(\mathrm{n}=3)\end{array}$ & $\begin{array}{r}5059 \\
220 \\
2642\end{array}$ & 3696 \\
\hline Bowen & upland/plain $(\mathrm{n}=20)$ & 3381 & 3381 \\
\hline Nocoleche & $\begin{array}{l}\text { bank }(\mathrm{n}=4) \\
\text { creek }(\mathrm{n}=5) \\
\text { floodplain }(\mathrm{n}=1) \\
\text { upland/plain }(\mathrm{n}=10)\end{array}$ & $\begin{array}{r}339 \\
497 \\
610 \\
181\end{array}$ & 313 \\
\hline Marathon & $\begin{array}{l}\text { puddle/gilgai }(\mathrm{n}=6) \\
\text { bank }(\mathrm{n}=5) \\
\text { creek }(\mathrm{n}=2) \\
\text { upland/plain }(\mathrm{n}=6)\end{array}$ & $\begin{array}{c}192 \\
354 \\
64 \\
354\end{array}$ & 272 \\
\hline Allaru North & $\begin{array}{l}\text { bore-drain }(n=4) \\
\text { bank of drain }(n=6) \\
\text { upland/plain }(n=10)\end{array}$ & $\begin{array}{r}1039 \\
1150 \\
253\end{array}$ & 679 \\
\hline Garomna North & $\begin{array}{l}\text { creek-bed }(\mathrm{n}=7) \\
\text { bank }(\mathrm{n}=3) \\
\text { upland }(\mathrm{n}=9)\end{array}$ & $\begin{array}{c}613 \\
385 \\
80\end{array}$ & 359 \\
\hline
\end{tabular}

\section{Population Structures}

Population profiles show a higher frequency of individuals between 100 and $300 \mathrm{~cm}$ high at cattle-grazed as compared with sheep-grazed sites (Figs 2 and 3). This is also apparent when expressed as a percentage of the total population (Table 3 ) and is statistically significant by t- test $(\mathrm{p}=0.0284)$. The few individuals under $300 \mathrm{~cm}$ present at the 4 sheep-grazed sites were heavily browsed and dwarfed, and may have been considerably older than expected for those height classes. These are indistinguishable from recent recruits in the histograms, highlighting a problem of using height as a surrogate for age. The browsed dwarfs were particularly noticeable at Garomna (both North and South) and Allaru South. In many cases these had died. Individuals between 100 and $300 \mathrm{~cm}$ high were almost entirely absent from the remaining sheep-grazed site (Allaru North). Individuals below $300 \mathrm{~cm}$ at the cattle-grazed sites (Giru, Bowen, Nocoleche and Marathon) showed little sign of browsing.

\section{Seedling Survival}

Prickly acacia seedling losses were highest at the sheep-grazed site, Allaru North (88\%) (Fig. 4). Some plants were missing from their recorded positions and this could have been due to either trampling or grazing. However in some cases the nipped off stem of the seedling was located, indicating that at least some of the
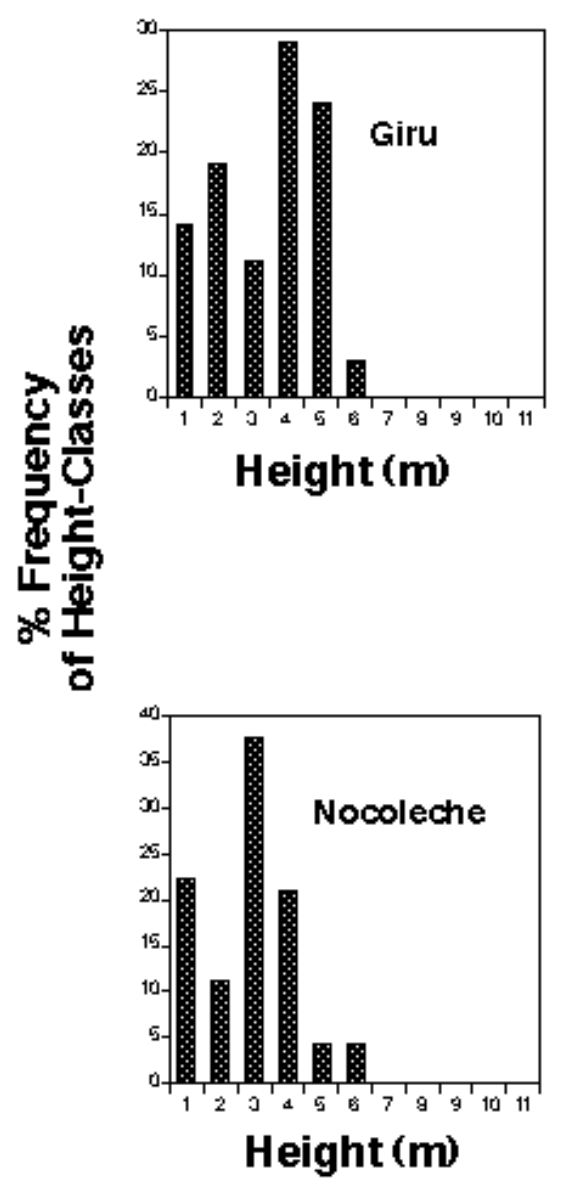
(low rainfall, cattle). losses were caused by grazing. Seedling losses were between 16 and $23 \%$ at cattlegrazed sites. Most mortality appeared to be due to trampling because there were hoofmarks present in most cases and the rings were often found kicked some distance away. Losses to grazing, presumably by insects, were very low (3\%) at the site which was ungrazed by sheep or cattle for the duration of the study, Garomna North.

\section{Discussion and Conclusions}

Prickly acacia populations are capable of reaching extremely high densities (over 3,000 shrubs $\mathrm{ha}^{-1}$ ) on high annual rainfall (> $900 \mathrm{~mm} \mathrm{year}^{-1}$ ) sites where they have formed impenetrable thickets, presenting a serious management problem. Populations of this density were not recorded in the low annual rainfall $\left(<500 \mathrm{~mm}\right.$ year $\left.^{-1}\right)$ rangelands to the west, the highest densities recorded in boredrains are about one fifth (just over 1,000 shrubs $h^{-1}$ ) of those
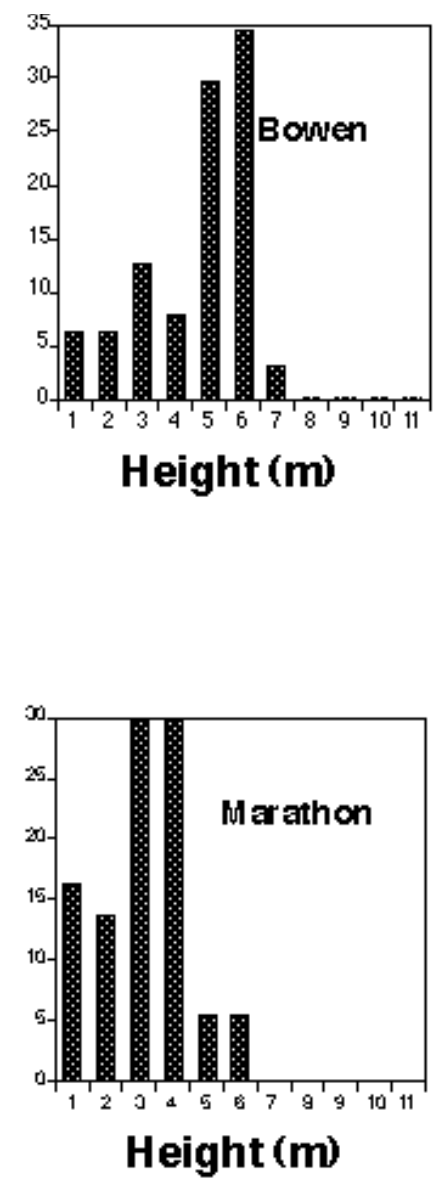

Fig. 2. Height structure profiles of prickly acacia (Acacia nilotica) populations at 4 cattlegrazed sites in central Queensland. Data are frequency percentages, height classes are as follows: $1=0-100 \mathrm{~cm} ; 2=101-200 \mathrm{~cm}$ etc) Rainfall and grazing histories are: Giru (high rainfall, cattle), Bowen (high rainfall, cattle), Nocoleche (low rainfall, cattle), Marathon 

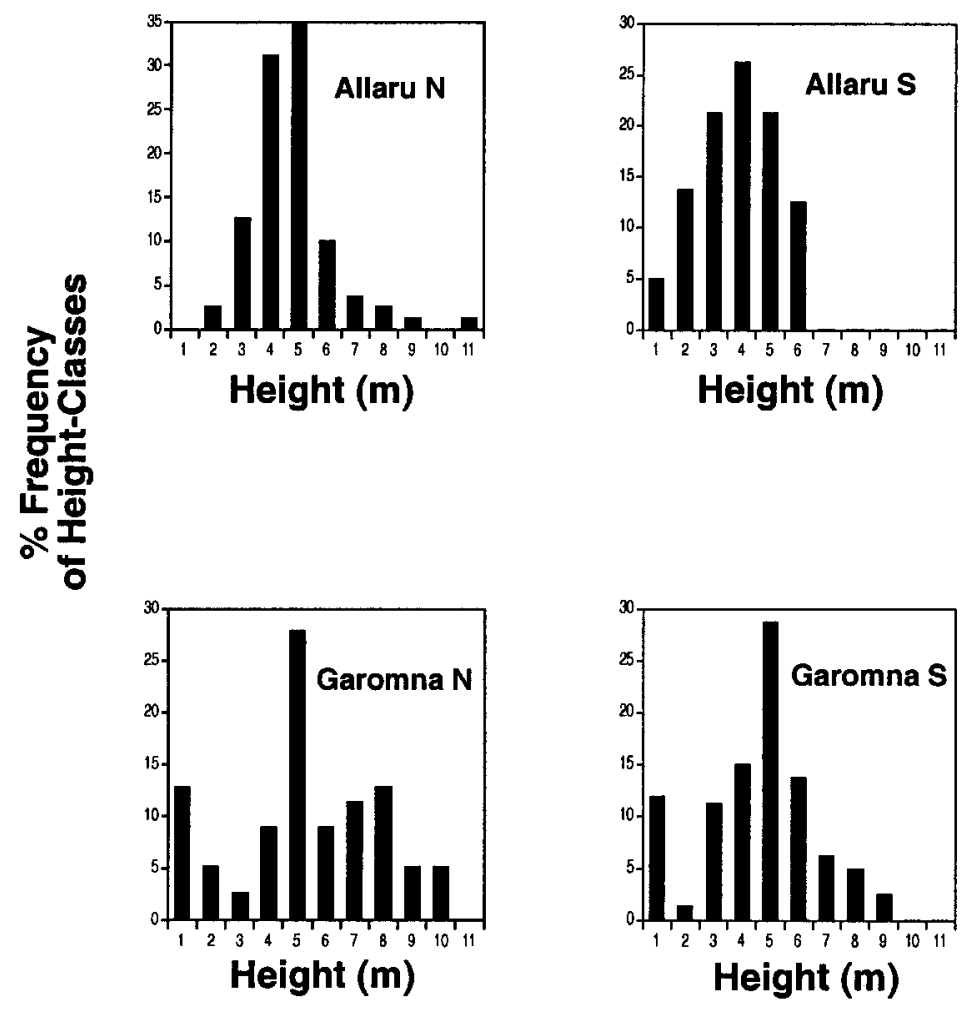

Fig. 3. Height structure profiles of prickly acacia (Acacia nilotica) populations at 4 low rainfall sheep-grazed sites in central western Queensland. Data are frequency percentages, height classes are in metres. Rainfall and grazing histories are: Allaru North (sheep, some cattle), Allaru South (sheep, some cattle), Garomna North (sheep only), Garomna South (sheep only).

from high rainfall areas. However, the high percentages of individuals in the lowest size classes on cattle-grazed properties at low annual rainfall indicate a rapid rate of regeneration in recent years, so we predict increases in both density and area infested by prickly acacia on cattle properties in central western Queensland unless appropriate management procedures are undertaken.

Prickly acacia seedlings and juveniles have lower survival on sites where sheep are present, whether by consumption or trampling of young seedlings, or by repeated browsing of older juveniles. We saw no evidence that cattle graze prickly acacia seedlings, in accordance with Barker (1996) who found no evidence for herbivore suppression of recruitment in prickly acacia, though there were some losses due to trampling in heavily used areas. The cohort of young seedlings in the sheep paddock completely disappeared within the first month, due to a combination of trampling and direct herbivory. The heavily grazed and dwarfed individuals which were observed at 2 of the sheepgrazed sites indicates that sheep will browse prickly acacia beyond the seedling stage, which may eventually lead to death of the plant. Continuous browsing over a number of years would inevitably reduce photosynthetic area, limit growth, and prevent the formation of an extensive root system, presumably making these individuals more drought-susceptible.

This is the first direct evidence of sheep suppressing regeneration of prickly acacia, although suppression of regeneration by sheep has been shown in other woody species (Pressland 1975, Lange and Purdie

Table 3. Percentage of prickly acacia (Acacia nilotica) juveniles 100 to $300 \mathrm{~cm}$ height at each of the 8 sites. Differences in mean between cattle-grazed and sheep-grazed sites are significant $(t=$ 2.872, $\mathrm{df}=6, \mathrm{p}(2$-tail $)=0.0284)$.

\begin{tabular}{lllll}
\hline \hline Site & $\begin{array}{c}\text { A. nilotica } \\
100-300 \mathrm{~cm}\end{array}$ & Mean & S. D. & S.E. \\
\hline Grazed by Cattle & & $(\%)$ & & \\
Giru & 30.0 & & & \\
Bowen & 32.8 & & & \\
Nocoleche & 48.6 & 38.662 & 8.741 & 4.37 \\
Marathon & 43.25 & & & \\
Grazed by Sheep & 12.82 & & & \\
Allaru North & 35.0 & & & \\
Allaru South & 7.59 & 17.142 & 12.175 & 6.087 \\
Garomna North & 13.16 & & \\
Garomna South & &
\end{tabular}

1976, Crisp 1978, Miller and Halpern 1998, Tiver and Andrew 1997), and by other herbivores (Myster and McCarthy 1989). As observed in Lange and Purdie's (1976) A. papyrocarpa Benth. study, sheep-browsed dwarves may survive as stunted, non-reproductive individuals for months or even years before finally succumbing. Previous studies of Acacia nilotica have concluded that neither sheep nor goats had any effect on juveniles (Carter and Cowan 1993). Grazing induced mortality may only occur when years of biomass reduction by repeated browsing are combined with drought conditions, a process not detectable in short-term grazing trials. Milton (1994) attributed mortality of populations of 3 species of shrubby Asteraceae to factors other than defoliation, but the study indicated that grazing could have a substantial effect on growth form and reproductive success. Similarly, grazing by prairie dogs (Cynomys spp.) limits recruitment of Prosopis glandulosa in grasslands of southwestern North America (Weltzin et al. 1997).

It appears that the lower regeneration of prickly acacia at sheep-grazed sites is due to a combination of trampling and grazing of young seedlings, and browsing and stunting of juveniles as long as their canopies remain within browse range. The reintroduction of sheep, either alone or in a grazing rotation with cattle, could be a useful control measure for prickly acacia in western Queensland, at least preventing further increases in density and spread on already infested properties. Unfortunately sheep do not thrive in the wet humid conditions which prevail on the coast, so alternative methods of control will be required there.

Anecdotal evidence that prickly acacia has become much more of a problem in the Mitchell Grass Plains of central western Queensland since many properties 

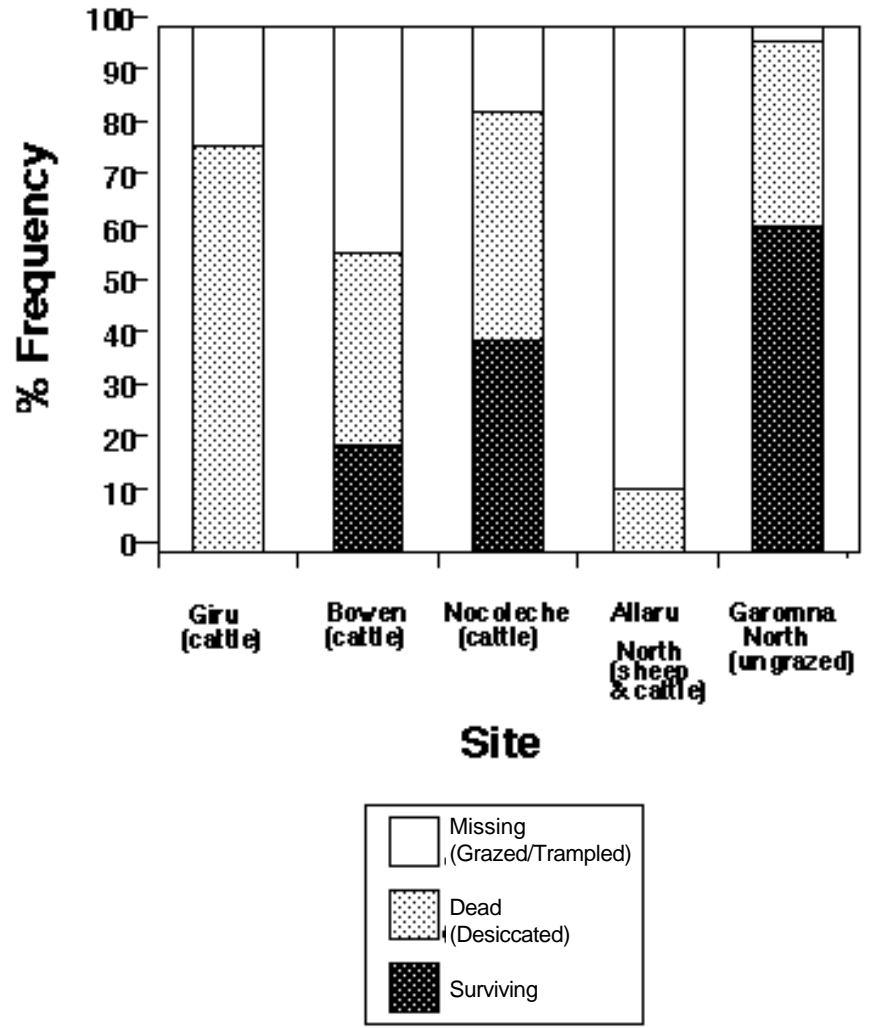

Fig. 4. Percentage losses by desiccation, missing (either trampled or grazed) and survival in cohorts of prickly acacia (Acacia nilotica) seedlings at 5 locations in central Queensland. Seedling cohorts germinated during the wet season January 1996 rains and their progress was followed until July 1996.

have been changed from sheep to cattle enterprises is supported. This also explains why landholders who still run sheep are much less concerned than others about the pest potential of prickly acacia (Brown and Carter 1998). Where sheep are still present, prickly acacia seedlings have not survived in large numbers since the major germination event which occurred during $1973 / 74$, and some landholders even expressed concern that older trees were dying off and not being replaced rapidly enough to maintain a good source of drought fodder and shade for their livestock (B. Fells, pers. comm.) Alternatively, on properties without sheep, prickly acacia seedlings have had high survivorship over the last 25 years and density has continued to increase since 1973/74 (Brown and Carter 1998). Landholders on cattle properties were more concerned about the pest potential of prickly acacia, since its value as fodder and shade could be negated by the costs of increased difficulty in management of stock and possible losses of grass fodder by shading and competition.

The episodic La Niña generated mass recruitment in prickly acacia and other woody weeds may present particularly dif- ficult management problems. Harrington (1991) suggested that although competition from grasses was important in limiting the survival of woody plant seedlings in most years, climatic conditions were occasionally adequate for mass establishment and that post-establishment disturbances such as fire would be critical to managing shrub populations. Mortality due to desiccation of prickly acacia seedlings may reach $60 \%$ within the first few months post-emergence. Even higher mortality of seedlings is found in other arid zone shrubs including narrow-leaved hopbush (Dodonaea viscosa Jacq. ssp. angustissima DC., syn. D. attenuata Cunn.), a native increaser species of southern Australian rangelands. Harrington (1991) estimated from watered pot trials that in only 6 out of 97 years have soil moisture levels been sufficient to allow widespread recruitment in western New South Wales. Callitris columellaris F. cation (100\% in 18 months) even during a high rainfall season in South Australia (Read 1995), further indicating that pulses of regeneration in many native shrubs rely on La Niña episodes of heavy prolonged Muell. shows high seedling loss to desic- rain and flooding followed by several successive years of high aggregate rainfall which provide follow-up rains for establishment. Similarly high desiccation rates of seedlings of Acacia ligulata Cunn. ex Benth. and Casuarina cristata Miq. ssp. pauper F. Muell. (variable, up to $80 \%$ ) were shown within the first couple of (dry) years after emergence in western New South Wales (Auld 1995). Prickly acacia is not as prone to desiccation as these species, and given the high seed loads, it seems likely that at least some plants establish in most years, but as with other shrubs in the arid zone there are pulses of recruitment during high rainfall years associated with La Niña events (Brown and Carter 1998). The effects of La Niña generated recruitment flushes of prickly acacia in the Mitchell grasslands have probably been amplified because of the replacement of sheep by cattle as the dominant herbivores.

\section{Control of prickly acacia}

We suggest that prickly acacia is more likely to become a management problem on cattle properties than sheep properties in the Mitchell grasslands. At present in these areas it is only at high densities in creeklines and boredrains. Densities are lower on upland sites but populations are continuing to regenerate rapidly, suggesting that further increases in density and spread are likely. Of prime concern are the prickly acacia infestations under higher rainfall regimes such as those on the east coast of Queensland where it is able to form dense unmanageable thickets on most landscape types. As a priority, management strategies should aim to prevent further spread of prickly acacia from property to property in eastern Queensland and to prevent introduction of prickly acacia into other regions in Queensland, Western Australia, the Northern Territory and northern New South Wales where computer modelling predicts that the climate would support severe infestations (Kriticos 1997). The most effective means of preventing spread will be by quarantining cattle from infested properties before transporting them to other properties within Queensland or interstate. An appropriate quarantine period would be 6 days, the time taken for seeds to pass through the digestive tract of cattle (Carter and Cowan 1993). Quarantining livestock for a brief period before moving between paddocks should also be effective in preventing further spread on infested properties.

Control techniques which are attuned to the ecology of the pest species concerned, 
and to the processes of the ecosystem within which it occurs are more likely to be effective. Relatively minor changes in management such as the use of an alternative species of livestock which can browse the pest plant more effectively may be a very economical means of achieving control. Sheep may be used in inland lowrainfall areas, but do not thrive in very high rainfall areas. In the low-rainfall Mitchell Grasslands of central western Queensland, sheep grazing may be sufficient to control the levels of prickly acacia recruitment experienced in most seasons. However, when mass recruitment occurs associated with prolonged rainfall and flooding it is highly unlikely that even with sheep grazing at moderate to high levels, that there would be adequate grazing pressure to defoliate all seedlings. Some plants would always establish during the periodic La Niña phases which occur about every 20 years in eastern Australia. In addition, the increased availability of palatable herbage in high rainfall years may reduce the relative acceptability of prickly acacia seedlings at precisely the time when suppression by hervivory would be required to control shrub numbers. This phenomenon has been observed with rabbits grazing western myall (Acacia papyrocarpa) in enclosures with and without available herbage (Lange and Graham 1983), and may help explain the widespread establishment of prickly acacia on both sheep and cattle properties during 1974/75. During such establishment periods, the stocking rates of sheep required to achieve control would most likely be deleterious to the survival of desirable native shrub species, and also cause soil erosion and compaction. So, although grazing by sheep may prevent increases in population density in most years, there may still be peaks of regeneration during La Niña wet periods.

The recovery of the Giru population to extremely high densities only 15 years after chaining demonstrates the ability of prickly acacia to regenerate following top removal. These results suggest that chaining cannot be recommended as a control measure for prickly acacia in high rainfall areas, unless some form of follow-up treatment is applied. Chaining is very expensive and should only be used in situations and seasons where there is likely to be a successful outcome, such as at lower rainfall sites, especially if carried out during droughts.

Other combinations of ecologially attuned control methods may be appropriate for prickly acacia. Such control prac- tices have already been used with some success in other species, particularly for mesquite (Prosopis spp) in North America (Jacoby 1985, 1986), and should be considered for the control of leguminous shrubs in other tropical grasslands, such as prickly acacia in Queensland. After widespread recruitment episodes, fire may be used to control shrubs, an alternative technique which has been found useful with other woody weed species in northern Queensland (Grice 1997) and the USA (Ortmann et al. 1998). Fire is an attractive and cheap treatment considering that fodder availability far exceeds that required for herd use during high rainfall years. The possibilities for cost-effective control of prickly acacia by controlled burning should be investigated. Some (presumably) native insects were observed to cause seedling mortality, although only at low percentages. There may be some value in importing and testing insect species which consume either seeds or, more particularly, seedlings of prickly acacia. A national program to cap freeflowing artesian bores should also reduce the area of key habitat where Acacia nilotica can rapidly establish, thus providing a regular source of seed for cattle to spread to upland landscapes.

\section{Literature Cited}

ABM 1996. Climatic records. Australian Bur. of Meteorology Telephone Advis. Serv., Brisbane.

Adamson, D.A. and M.D. Fox 1982. Change in Australasian vegetation since European settlement. p. 109-160 In: J.M.B. Smith (eds), A history of Australasian vegetation. McGraw-Hill, Sydney.

Archer, S. 1989. Have southern Texas savannas been converted to woodlands in recent history? Amer. Nat. 134: 545-561.

Archer, S. 1994. Woody plant encroachment into Southwestern grasslands and savannas: rates, patterns and proximate causes. p. 13-68 In: M. Lavra, W. Laycock and R. Pieper (eds), Ecological implications of livestock herbivory in the West. Soc. for Range Manage., Denver, Colo.

Auld, T.D. 1995. The impact of herbivores on regeneration in four trees from arid Australia. Aust. Rangel. J. 17: 213-227.

Barker, M. 1996. Literature review: The ecology and management of Acacia nilotica subsp. indica (Benth) Brenan. p. 38-53 In: F. Tiver, B. Wilson and W. Forno (eds) Proc. Woody Weeds Workshop, 16th and 17th March 1995, CSIRO Davies Laboratories, Townsville. CSIRO Division of Tropical Crops \& Pastures.

Blake, S.T. 1938. The plant communities of Western Queensland and their relationships with special reference to the grazing industry. Proc. Roy. Soc. Qld XLIX: 156-204.
Brown, J.R. and S. Archer 1987. Woody plant seed dispersal and gap formation in a North American subtropical savanna woodland: the role of domestic herbivores. Vegetatio 73:73-80.

Brown, J.R. and S. Archer 1989. Woody plant invasion of grasslands: establishment of honey mesquite (Prosopis glandulosa var. glandulosa) on sites differing in herbaceous biomass and grazing history. Oecologia 80: 19-26.

Brown, J.R. and J. Carter 1998. Spatial and temporal patterns of exotic shrub invasion in an Australian tropical grassland. Landscape Ecol. 13:93-102.

Carter, J.L. 1994. The spatiotemporal pattern of an Acacia nilotica (prickly acacia) invasion into the Mitchell grasslands. Honours Thesis, James Cook Univ. of North Queensland.

Carter, J.O. and D.C. Cowan 1993. Population dynamics of prickly acacia, Acacia nilotica subsp. indica (Mimosaceae). p. 83-104 In: E.S. Delfosse (eds), Pests in pastures: weed, invertebrate and disease pests of Australian sheep pastures. CSIRO Information Services, Melbourne.

Carter, J.O., P. Jones, and D.C. Cowan 1991. Control of woody weeds in western Queensland. Rep. to the Australian Wool Corp., Queensland Dept. of Primary Industries.

Cottam, G. and J.T. Curtis 1956. The use of distance measures in phytosociological sampling. Ecol. 37: 451-460.

Crisp, M.D. 1978. Demography and survival under grazing of three Australian semi-desert shrubs. Oikos 30: 520-528.

Greig-Smith, P. 1983. Quantitative plant ecology. Third edition. University of California Press, Berkeley and Los Angeles, Calif.

Grice, A.C. 1997. Post-fire regrowth and survival of the invasive tropical shrubs Cryptostegia grandiflora and Ziziphus mauritiana. Aust. J. Ecol. 22: 49-55.

Harper, J.L. 1977. Population biology of plants. Academic Press, London.

Harrington, G.N. 1979. The effects of feral goats and sheep on the shrub populations in a semi-arid woodland. Aust. Rangel. J. 1: 334-345.

Harrington, G.N. 1991. Effects of soil moisture on shrub seedling survival in a semi-arid grassland. Ecology 72: 1138-1149.

Harrington, G.N., M.H. Friedel, K.C. Hodgkinson, and J.C. Noble 1984. Vegetation ecology and management. p. 4177 In: G.N. Harrington, A.D. Wilson and M.D. Young (eds), Management of Australia's rangelands. CSIRO, Melbourne.

Harvey, G.J. 1981. Recovery and viability of prickly acacia (Acacia nilotica ssp. indica) seed ingested by sheep and cattle. p. 34-45 In: B.J. Wilson and J.T. Swarbrick (eds) Proc. 6th Australian Weeds Conf., Brisbane. Queensland Weed Soc..

Hennessy, J.T., R.P. Gibbens, J.M. Tromble, and M. Cardenas 1983. Vegetation changes from 1935 to 1980 in mesquite dunelands and former grasslands of southern New Mexico. J. Range Manage. 36: 370-374. 
Holmes, P.M. and R.M. Cowling 1997. The effects of invasion by Acacia saligna on the guild structure and regeneration capabilities of South African fynbos shrublands. J. Appl Ecol. 34: 317-332.

Humphries, S.E., R.H. Groves, and D.S. Mitchell 1991. Plant invasions of Australian ecosystems. A status review and management directions. Australian National Parks and Wildl. Serv., Canberra.

Jacoby, P.W. 1985. Restoring mesquite savanna in western Texas, USA, through brush and cacti management. p. 223-228 In: J.C. Tothill and J.J. Mott (eds), Ecology and management of the world's savannas. Australian Acad. of Sci., Canberra.

Jacoby, P.W. 1986. Control and management of undesirable woody plants on semi-arid rangelands. p. 259-263 In: P.J. Joss, P.W Lynch and O.B. Williams (eds) Proc. Second International Rangeland Congress: Rangelands: a resource under seige, Adelaide, S.A. Australian Acad. of Sci.

Kent, M. and P. Coker 1992. Vegetation description and analysis: a practical approach. CRC Press \& Belhaven Press, Boca Raton, Ann Arbor, Mich. and London, England

Kriticos, D.J. (1997). A climatic analysis of the potential distribution of prickly acacia in Australia. A report prepared for Land Protection, Queensland Department of Natural Resources, Brisbane, Queensland and Cooperative Research Centre for Tropical Pest Management, Brisbane, Queensland.

Lange, R.T. and C.R. Graham 1983. Rabbits and the failure of regeneration in Australian arid zone Acacia. Aust. J. Ecol. 8: 377-381.
Lange, R.T. and R. Purdie 1976. Western myall, (Acacia sowdenii), its survival prospects and management needs. Aust. Rangel. J. 1: 64-69.

Miller, E.A. and C.B. Halpern 1998. Effects of environment and grazing disturbance on tree establishment in meadows of the central Cascade Range, Oregon, USA. J. Appl. Ecol. 9: 265-282.

Miller, M.F. 1994. Large African herbivores, bruchid beetles and their interactions with Acacia seeds. Oecologia 97: 265-270.

Milton, S.J. 1994. Growth, flowering and recruitment of shrubs in grazed and in protected rangeland in the arid Karoo, South Africa. Vegetatio 111:17-27.

Moore, C.W.E. 1969. Application of ecology to the management of pastoral leases in northwestern New South Wales. Proc. Ecol. Soc. Aust. 4: 39-54.

Myster, R.W. and B.C. McCarthy 1989. Effects of herbivory and competition on survival of Carya tomentosa (Juglandaceae) seedlings. Oikos 56:145-148.

Nicholls, N. 1991. The El Niño/Southern Oscillation and Australian vegetation. Vegetatio 91: 23-36.

Ortmann, J., J. Stubbendieck, R.A. Masters, G.H. Pfeiffer,and T.B. Bragg 1998. Efficacy and costs of controlling eastern redcedar. J. Range Manage. 51:158-163.

PNSW 1901. Royal commission to inquire into the condition of the crown tenants of the Western Division of New South Wales. Part 1. Report and summary of evidence. Votes and proceedings of the New South Wales Legislative Assembly during the session of 1901 , with the various documents connected therewith. 4:131-66. Parliament of New South Wales, Sydney.
Pressland, A.J. 1975. Productivity and managementof mulga in south-western queensland in relation to tree structure and density. Aust. J. Bot. 23:965-976

Read, J. 1995. Recruitment characteristics of the white cypress pine (Callitris glaucophylla) in arid South Australia. Rangel. J. 17: 228-240.

Silvertown, J. and J. Lovett-Doust 1993. Introduction to plant population biology. Blackwell Scientific Publications, Oxford.

Skarpe, C. 1990. Shrub layer dynamics under different herbivore densities in an arid savanna, Botswana. J. Appl. Ecol. 27:873-885.

Tiver, F. and M.H. Andrew 1997. Relative effects of herbivory by sheep, rabbits, goats and kangaroos on recruitment and regeneration of shrubs and trees in eastern South Australia. J. Appl. Ecol. 34:903-914.

Weltzin, J.F., S. Archer, and R.K. Heitschmidt 1997. Small-mammal regulation of vegetation structure in a temperate savanna. Ecology 78:751-63. 